\title{
Mustafa Kemal Atatürk'ün Tarih Anlayışı İle İlgili Bazı Görüşler
}

\author{
Yrd. Doç. Dr. Haldun EROĞLU*
}

ÖZET

Mustafa Kemal Atatürk, asker, devlet adamı ve fikir adamı sıfatlarını haklı olarak üzerine alırken bu sıfatlarl üzerinde tașıyan bir kișinin tarih biliminden haberdar olması gerekliliği konusunda bir örnektir. Gerçekleştirdiği devrimlerde sahip olduğu tarih bilgisinden daima faydalanmıştı. Özel gayret göstererek kurduğu Türk Tarih Kurumu Türk milletine milli bir ruh vermek ve Türk tarihinin yeniden yazımını gerçekleştirmekle görevli idi. Mustafa Kemal Atatürk, daha öğrencilik yıllarından itibaren okuduğu tarih kitapları ile çok iyi bir tarihi birikime sahip olmuş ve bu bilgi birikiminden devlet yönetiminde faydalanmıştır.

Anahtar Kelimeler: Mustafa Kemal Atatürk, tarih, Türk Tarih Kurumu

\section{ABSTRACT}

Mustafa Kemal Atatürk had the attributes of soldier, statesman and ideaman, and also he was the sample for like that man should be informed about the history. In his revolutionary actions, he always used his historical informations. Turkish Historical Society which is found by himself, was in the charge of realizing the rewriting of Turkish history and to give national soul to the Turkish nation. Mustafa Kemal Atatürk by his school days, in his reading books he gained very large historical informations and he also used this historical informations in his governing the state.

Key Words: Mustafa Kemal Atatürk, history, Turkish Historical Society.

- Akdeniz Üniversitesi, Fen-Edebiyat Fakültesi Tarih Bölümü. halduneroglu@yahoo.com 
İnsanın ne oldu-ne olacak ile ilgili merakı onu araştırmaya yöneltir.. O'nun bu araştırması bilimsel bir sistematik olarak Tarih bilimini doğurdu.. Tarih özellikle on dokuzuncu yüzyılda modern bir bilim dalı haline geldi. Daha önceleri sadece varolanı kronolojik bir sıra halinde veren rivayetçi bir anlatımdan öte bir anlam ifade etmeyen tarih bilimi on dokuzuncu yüzyılda olagelen (dün) ile hadis (bugün) arasındaki ilişkiyi kurarak, olması muhtemel (yarın) ile ilgili fikirler ileri sürmeyi amaçlayan bir bilim dalı olarak yeniden şekillendi. Bu açıdan tarih bilimi, statik (durağan-geçmişle ilgili/geçmişte kalmış) değil dinamik (aktif-gelecekle de ilgili)tir. Arap filozof İbn Haldun daha on dördüncü yüzyılda kendinden öncekiler ve çağdaşlarından farklı olarak ilk defa tarihçinin tarihi verileri sorgulamasının, kritik etmesinin gereğini vurgulayarak ${ }^{1}$ tarihçiliğe yeni bir yol açmış fakat bu yol ancak on dokuzuncu yüzyılda modern tarihçiliğin doğmasıyla genişlemiştir.

Tarihçi açısından bugün dünyada yaşananlar dün yaşanmış olanlarla yakından ilgilidir. Bu, tarihin neden-sonuç ilişkisi ile ilgilidir. Olanı doğru algılayabilmek ve anlamak, olacağa dair öngörülerde bulunmak ancak iyi bir tarih bilgisi ve bilinci ile gerçekleşebilir. ${ }^{2}$

$\mathrm{Bu}$ açıdan bakıldığında tarih boyunca, gerek imparatorluklar zamanında gerekse modern devletler döneminde iyi bir hükümdar yada yönetici olan kişilerin, çok iyi tarih bilgisi ve bilincine sahip olmaları gereği kendini göstermektedir. Devlet adamlığı vasfının en önemli unsuru, olanı bilmek ve olacak olan hakkında yerinde tespitler yapmak, yani ileri görüsşlülük, olduğu bugün herkes tarafından kabul edilen bir gerçektir. Bu açıdan ileri görüşlülük için olmuş olanın nelere yol açtığını, yani diğer bir değişle tarih metodolojisinin olmazsa olmazı neden-sonuç ilişkisini bilmekten geçtiği kabul edilmelidir.

Bugünkü Türkiye Cumhuriyetini kuran ve onu sağlam temeller üzerine oturtan büyük önder Mustafa Kemal Atatürk'ün tarih bilgisi, bilinci ve tarih bilimine verdiği önem bu açıdan bütün liderlere ve insanlığa ders olacak kadar yerinde bir örnektir. Bu çalışma ile Mustafa Kemal Atatürk'ün bu yönünü ortaya çıkarmaya yönelik diğer çalışmalara ${ }^{3}$ katkı yapmak

1 İbn Haldun, Mukaddime, c. I, M.E.B. yay. (çev. Zakir Kadiri Ugan), İstanbul 1989, s. $18-82$.

2 Tarih metodolojisi ile ilgili olarak bkz. Ernest Bernheim, Tarih İlmine Giriş, (çev. Şükrü Akkaya), İstanbul 1936. Marc Bloch, Tarihin Savunusu ya da Tarihçilik Mesleği (çev. Mehmet Ali Kılıçbay), Ankara 1985. Güstav le Bon, Tarih Felsefesinin İlmi Esasları (çev. Haydar Rıfat), İstanbul 1932, Edward Hallet Carr, Tarih Nedir? (çev. Misket Gizem Gürtürk), İstanbul 1980. Leon E. Halkın, Tarih Tenkidinin Unsurları (çev. Bahaeddin Yediyıldız), Ankara 1989. Ekrem Memiş, Tarih Metodolojisi, Konya 1989. Gabriel Monod, Tarihte Usul, (çev. Kazım Şinasi Dersan), İstanbul 1938. Zeki Velidi Togan, Tarihde Usul, (3. Baskı), İstanbul 1981.

${ }^{3} \mathrm{Bu}$ çalışmalardan bazıları şunlardır. Şemsettin Günaltay, “Atatürk'ün Tarihçiliği ve Fahri Profesörlüğü Hakkında Bir Hatıra”, Belleten III/10, (Nisan 1939), s. 273-274, Hasan 
amaçlanmaktadır. Bu amaca yönelik olarak çalışmaya temel kaynak olarak, Mustafa Kemal Atatürk'ün okuduğu kitaplar ve bu kitapların kenarların düştüğg̈ notlar yada çizdiği sayfaların günümüz Türkçesine aktarımının yapıldığı, Atatürk'ün Okuduğu Kitaplar ${ }^{4}$ adlı eser alınmıştır. Bu sayede o'nun okuduğu tarih kitapları ve görüşleri irdelenerek tarih bilgisi ve bilinci yani tarihçiliği bu yönüyle ortaya çıkarılmaya çalışılacaktır. Adı geçen bu eser göstermektedir ki Mustafa Kemal Atatürk’ün düşün dünyasının oluşumunda hemen her konuda kaleme alınmış kitaplarının etkisi çok büyüktür. ${ }^{5}$ Okuduğu kitaplar içerisinde ise, bu makaleye konu olan Mustafa Kemal Atatürk'ün tarihçiliği ile ilgili olarak, tarih kitaplarının ağırlığı kendini göstermektedir. Özellikle bu kitapların kenarlarına düştüğü notlar ve önemli gördüğü yerlerin altını çizdiği bölümler tarih bilgisinin ve bilincinin oluşumundaki etkenleri açığa çıkarmaktadır.

Mustafa Kemal Atatürk'ün devlet, asker ve fikir adamı olarak ortaya çıkan kişiliğinin oluşumunda tarih biliminin önemi oldukça fazladır. Tarihe olan ilgisi daha öğrencilik yıllarında başlayan Mustafa Kemal Atatürk'ün Türkiye Cumhuriyetini kurmasından sonra özellikle Türk Tarih Kurumunu kurdurması, bu kurumun çalışmalarına katılarak yakından ilgilenmesi tarihe ve tarih bilimine verdiği önemi göstermesinin yanı sıra OsmanlıdanCumhuriyete (ümmetten-millete) geçiş sürecinde Türk milletine, millet olma bilincini aşılamak amacını da gütmektedir. ${ }^{6}$ Mustafa Kemal Atatürk'ün düşün dünyasının oluşmasında ve tarih bilgisi ve bilinci kazanmasında daha öğrencilik yıllarından itibaren okuduğu kitapların önemi çok büyüktür. Mustafa Kemal Atatürk'ün okuduğu sanat, ekonomi, genel kültür, siyaset, düşünce dünyası, askẹri içeriklerden oluşan kitaplar arasında büyük oranda yer kaplayan tarih kitaplarının ayrı bir yer tuttuğunu hatta büyük

Cemil Çamlıbel, “Atatürk ve Tarih”, Belleten III/10, (Nisan 1939), s. 269-272, Ekrem Akurgal, "Tarih İlmi ve Atatürk", Belleten XX/80, (Ekim 1966), s. 571-584, Halil İnalcık, "Türk Tarihi ve Atatürk’te Tarih Şuuru”, Türk Kültürü, S. 7, (Mayıs 1963), s. 6-11, Bekir Sitkı Baykal, "Atatürk ve Tarih", Belleten XXXV/140, (Ekim 1971), s. 531-540, Enver Ziya Karal, "Atatürk ve Tarih", Türk Dili, XV/170, (Kasım 1965), s. 71-74, Mehmet Saray, “Atatürk ve Türk Tarihi”, Türk Külttürü, XXII/249, (Ocak 1984), s. 1-18, Yavuz Ercan, “Atatürk ve Tarih", Amme İdaresi Dergisi, XXI/6, (Aralık 1988), s. 15-23, Ayfer Özçelik, "Atatürk ve Tarih Şuuru”, Atatürk Araştırma Merkezi Dergisi, XII/35, (Temmuz 1996), s. 601-607, Sevcihan Özer, "Atatürk ve Türk Tarihi”, Atatürk Araştırma Merkezi Dergisi, XV/44, (Temmuz 1999), s. 761-769, İsmail Özçelik, “Atatürk, Cumhuriyet ve Tarih Şuuru”, Erdem, Atatürk Kültür Merkezi Dergisi, XI/31 (Özel Sayı 1999), s. 179-195, Sabri Hizmetli, “Atatürk ve Tarih”, Askeri Tarih Bülteni, XVIII/35, (Ağustos 1993), s. 13-20,

${ }^{4}$ Atatürk'ün Okuduğu Kitaplar, Anıtkabir Yay, c. I-XXIV,. Ankara 2001.

${ }^{5}$ Mustafa Kemal Atatürk'ün düşün dünyasının oluşumu ile ilgili bkz. H. Eroğlu, "Mustafa Kemal Atatürk!ün Düşün Dünyasının Oluşumundaki Etkenlerle İlgili Bazı Görüşler”, Ankara Üniversitesi Türk İnkılap Tarihi Enstitüsü Atatürk Yolu Dergisi, VII/27-28, (Mayıs-Kasım 2004), s. 285-298.

${ }^{6}$ Mustafa Kemal Atatürk'ün millet ve milliyetçilik fikirleri ile ilgili geniş bilgi için bkz. Mustafa Keskin, “Atatürk'e Göre Millet ve Türk Milliyetçiliği” Atatürk Araştırma Merkezi Dergisi, XIV/41, (Temmuz 1998), s. 359-374. 
çoğunluğunu oluşturduğunu da ilave etmek gerekir. Mustafa Kemal Atatürk'ün okuduğu bu kitaplarda sadece önemli gördüğü yerlerinin altını çizdiği ve yanlarına not düştüğü kısımların günümüz Türkçesine aktarımının

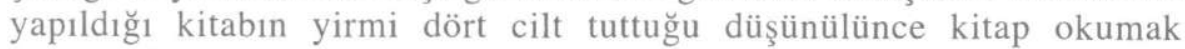
konusunda ne kadar duyarlı olduğu ve düşün dünyasının oluşumunda ve bilgi birikiminde bunun ne kadar önemli bir yer teşkil ettiği daha iyi anlaşılır. Aynı şekilde yirmi dört ciltlik kitabın yarısından fazla kısmını tarih kitaplarının oluşturduğu görülünce de tarihe olan ilgisi daha net anlaşılmaktadır.

Mustafa Kemal Atatürk'ün okuduğu kitaplar arasında yer alan tarih kitaplarından bazıları şunlardır. Hunların Türklerin Moğolların ve Sair Diğer Tatarların Tarih-i Umumisi (Deguignes), Türk Tarihi (Rıza Nur), Osmanlı Tarihi (Necip Asım- Mehmet Arif), Yeniçağdan Günümüze Türkiye Tarihi (Ahmet Hamit- Mustafa Muhsin), Van Tarihi, Antalya Livası Tarihi (S. Fikri Erten), Türk Medeniyeti Tarihi (Ziya Gökalp), Osmanlı Tarihi (Ahmet Rasim), Tarih-i Osmani (Ali Reşat), Şecere-i Türk (Ebulgazi Bahadır Han), Cihan Tarihinin Umumi Hatları (H. G. Wells), Tarih-i İslam (Filibeli Ahmet Hilmi), Umumî Tarih (Ahmet Refik), Türk Tarihi (Necip Asım), İslam Tarihi (Leon Caetani/terc. Hüseyin Cahit), Umumi Tarih (Ali Reşat), İslam Tarihi (M. Şemseddin), Tevarih-i Al-i Osman (Așıkpaşazâde), Orhun Abideleri (Necip Asım), Endülüis Tarihi, (Ziya Paşa), Tarih-i Devlet-i Osmaniye (Abdurrahman Şeref), Büyük Tarihi Umumî (Ahmet Refik), Düvel-i İslamiye (Poole Stanley Lane/terc. Halil Edhem), İlkçă̆ Tarihi (Eduard Meyer), Romalıların Tarihi (Victor Duruy), Doğu ve Yunan (Ch Aımond), Eski Çă̆ Doğu-Yunan-Roma (Albert Malet), Doğu Halklarının Eski Tarihi (G. Maspero), Batı İmparatorluğunun Son Dönemi (Amedee Thierry), Doğunun Eski Tarihi (Françosi Lenormnt), İsrail Halkının Tarihi (Ernest Renan), Eski Çin (Henri Maspero), İlk Uygarlıklar (Güztave Fougeres), Yunan Halkının Oluşumu (A. Jarde), Insan ve Dïnya (Elisee Reclus), Dünya Tarihi Özeti (H. G. Wells), Nil Nehri ve Misır Medeniyeti (A. Moret), Mısır'ın Dramı (Raymont Colrat), Uzak Doğu Tarihi (Rene Grousset), Moğol Imparatorluğu (Lucien Bouvat), Asya Tarihi (Herbert H. Gewen), Fransa Nereye Gidiyor? Avrupa Nereye Gidiyor? (J. Callaux), İsveç ve Norveç (Ph. Le Bas), Çağdaş Avrupa Siyasi Tarihi, (Charles Seignobos), Barbarlar (Louis Halphen), Osmanlıların Ülkesi (G. Des Godıns De Souhesmes), Dünya Savașının Tarihi (Amede Le Faure), Osmanlı İmparatorluğu Tarihi (Theophile Lavallee), Arapların Genel Tarihi (L. A. Sedillot), Baron De Tott'un Türkler ve Tatarlarla İlgili Yazlart (Baron François Tott), Orta Avrupa (Emm De Martonne), Okyanusya (Paul Privat Deschanel), Eski Asya (Andre Berthelot), Hindistan (Lois De La Vallee Poussin), Osmanlt İmparatorluğu Tarihi (Hammer), Eski Ve Modern Türkler (Mustafa Celalattin), Türklerin Örfleri Adetleri, Dinleri, Sivil, Askerî ve Siyasi Yönetimleri (M Guer), Çağdaş Tarih (Prens Lubomirski), Başlangıçtan Günümüize İngiltere Tarihi (Edouart Guyot), Modern Tarih (Ch. Aımond), 
Rusya'nın Tarihi (Alfret Nicolas Rambaud), Bizans'ın Yükselişi ve Çöküşü (Ch Diehl), Kutsal İttifak (A. Debidour), Fransa Tarihi (Henri Martin), Attilanın Hayatı (Marcel Brıo), İslam Tarihi Üzerine Denemeler (R. Dozy),

Mustafa Kemal Atatürk'ün tarih bilimine önem vermesi sadece amatör bir tarih okuyuculuğu ile sınırlı değildir. Okuduğu kitaplara göz atılacak olursa bu sayede sahip olduğu tarih bilgisinin, kendisini sadece tarih ilmine adamış bir bilim insanı kadar hatta ondan daha fazla olduğunu ileri sürmek yanlış bir değerlendirme değildir. Sadece tarih bilgisi değil tarih metodolojisi açısından söyledikleri tarihçiye yol gösterecek nitelik taşır. Atatürk'ün tarih biliminin metodolojisi ile ilgili görüşleri şu sözlerinde anlam bulur. "Herhangi bir tarihi elinize aldığınız zaman onun gerçeğe uygun olup olamadığına güven duymak için dayandığı kaynak ve belgeleri araştırılır. Bizim şimdiye kadar doğru bir millî tarihe mâlik olamayışımızın sebebi tarihlerimizin, hakiki okuyucularin belgelere dayanmaktan ziyade ya birtakım meddahların veya birtakım kendini be ğenmişlerin hakikat ve mantıktan uzak sözlerinden kaynak bulmamak bedbahtlığıdır." ${ }^{77} \mathrm{Bu}$ görüşle aynı zamanda rivayetçi tarih anlayışının ne kadar yanlış olduğunun altını çizerken aynı zamanda bugün modern tarihçilik olarak kabul edilen belgelere ve kaynaklara dayalı tarihçiliğge atıfta bulunmaktadır. Nitekim yine Mustafa Kemal Atatürk'ün bu konu ile ilgili olarak "Tarih yazmak tarih yapmak kadar mühimdir, yazan yapana sadık kalmazsa değişmeyen hakikat, insanlığı şaşırtacak bir mahiyet alır" sözü aslında modern tarihçilik anlayışının en önemli belirtisidir. Diğer yandan 1931 yılında Türk Tarih Kurumu Başkanı Tevfik Bıyıklığlu'na yazdığı mektubunda bu görüşünü tekrarlamaktadır:"Tarih yazmak için tutulan yolun bilhassa ilmî olması şarttır. Bu münasebetle yüksek heyetinizin reisi bulunan zât-l âlinize hatırlatırım ki, yeni dünya ufuklarına açacağınız yeni tarih semasında dikkatli olunuz. Sümmettedarik bir eser vücuda getirerek ferdasında nadim olmaktansa hiçbir eser vücuda getirmemek aczini itiraf etmek evladır. İlim sahasında vesveseli olmak, miskin müesseselerin mezunlarına inanmaktan evladir." 8

Mustafa Kemal Atatürk, modern tarihçiliğin temel taşlarından biri olan tarihin neden-sonuç ilişkisi ile ilgili de şunları söylemektedir: "İnsanların tarihten alabilecekleri mühim dikkat ve uyanıklık dersleri, bence devletlerin umumiyetle siyasi müesseselerin teşekküllerinde bu müesseselerin mahiyetlerini değiştirmede ve bunların çözülme ve sonlanmalarında müessir olmuş olan sebepler ve amillerin tetkikinden çıkan neticeler olmalıdır. Mesela Osmanlı Imparatorluğunun doğmasını gerektiren sebep ve amillerin tetkikinden çıkan netice, mühim olduğu gibi, bu imparatorluğun batmasına sebep ve amillerden çıkacak netice de o kadar mühimdir. Bu tetkiklerde

7 Özkan İzgi, “Atatürk'ün Tarih İlmî Hakkındaki Düşünceleri” Atatürk Araştırma Merkezi Dergisi, IV/10 (Kasım 1987), s. 133.

${ }^{8}$ İzi, a.g.m., s. 134. 
şüphesiz, siyasi müesseseyi kuran milletlerin her görüş noktasindan harslart derecesi mütalaa olunur; şahisların müsbet ve menfi tesirleri göz önüne alinir." 9

Mustafa Kemal Atatürk'ün millet hayatında dilin, tarihin, edebiyatın, sanatın çok önemli olduğu yönündeki fikirlerinin varlığı bilinmektedir. ${ }^{10}$ Nitekim okuduğu kitaplar arasında bu yönde kitapların ă̆ırlığı göze çarpmaktadır. Ancak bu yöndeki fikirlerinin temellerinin anlaşılması açısından okuduğu kitaplar arasında bulunan ve Alfred Feuillet tarafında kaleme alınan Avrupa Milletleri Ruhiyatı adlı eser dikkat çekicidir. Bu kitapta geçen bir paragraf Mustafa Kemal Atatürk tarafından kalın çizgilerle işaretlenmiştir. Bu cümlede yazar: "Bir milletin özellikleri: dili, tarihi, edebiyatı, sanatı uzun tarihinin ortalama olaylart alınarak siyasetinin incelenmesiyle anlaşılabilir. Ayn şekilde milletin evren ve hayata verdiğ $i$ kıymet ve anlam hakkındaki fikirleri de mutluluğu, felaketi ve olumlu özellikleri üzerine etki yapar. Dininin, felsefesinin, edebiyatının bir millet üzerine etkisi buradan gelmektedir."11

Mustafa Kemal Atatürk'ün Türk tarihini algılamadaki temel taşı, İslam öncesi dönemdeki Türk devletlerine kadar gider. Hatta Osmanlı kroniklerinde detaylı olarak çizilen Türk cetvellerindeki gibi Türk'ü Nuh'un oğlu Yafes'e kadar dayandırmakla birlikte tarihi delillerle ortaya koymaya çalıştı̆̆ı Türk tarihi; O'na göre milattan sonra beşinci yüzyıldan itibaren Asya'nın göbeğinde Türk milleti tarafından kurulmuştur. Bu Türk devleti sefirlerini Çin'e gönderen ve Bizans sefirlerini kabul eden "uluslar arast" bir devlettir. Anlaşıldığı gibi Mustafa kemal Atatürk, Türk tarihini Kök-Türk dönemine kadar götürmektedir. ${ }^{12}$ Diğer taraftan Asya'daki diğer Türkleri "kardeş devletler ve milletler" olarak adlandırmaktadır. ${ }^{13}$ Türk tarihindeki devletlerin yıkılıp yeniden kurulması ile ilgili olarak bu durumun ekonomik sebeplerden kaynaklandığını şu sözlerle ifade etmektedir."Türk tarihi tetkik olunursa bütün itila ve inhitat esbabının bir iktisat meselesinden başka bir şey olmadığı anlaşıllı... tarihimizi dolduran bunca muvaffakiyetler, zaferler veyahut mağlubiyetler, izmihlal ve felaketler, bunların kaffesi vukua geldikleri devirlerdeki ahvali iktisadiyemizle alâkadardır. "14

${ }^{9}$ İzgi, a.g.m., s. 136.

${ }^{10}$ Mustafa Kemal Atatürk'ün kültür ve sanat il ilgili görüşleri için bkz. İsmet Giritli, “Atatürk, Kültür ve Sanat" Atatürk Araştırma Merkezi Dergisi, IV/10 (Kasım 1987), s. 1926. Oktay Aslanapa, “Atatürk ve Sanat” Türk Kültürü, XXXVII/436, (Ağustos 1999), 458460, Türk dili ile ilgili görüşleri için bkz. Zeynep Korkmaz, "Milli Mücadele ve Sonrasında Türklük Şuuru” Atatürk Araştırma Merkezi Dergisi, IV/10 (Kasım 1987), s. 59-60.

"Atatürk'ün Okuduğu Kitaplar, c. V, s.. 324.

${ }^{12}$ Söylev ve Demeçler, c. I, s. 288.

${ }^{13}$ Söylev ve Demeçler, c. II, s. 24.

${ }^{14}$ Söylev ve Demeçler, c. II, s. 104. 
Türklerin İslam dini ile karşılaşması ve İslam'a girmeleri ile meydana getirdikleri Selçuklu devletinden bahsederken de yaklaşı bin sene önce Türklerin asker olarak Suriye'ye Irak'a kadar yayıldıklarını, Abbasi halifesinin idaresi altında yüksek makamlara kadar geldiklerini, Hicri dördüncü asırda (Miladi bininci asır/onuncu yüzyıl) Selçuklu hükümeti adı altında muazzam bir Türk devleti kurduklarını, sınırlarını Kafkasya'dan Suriye, İran ve Irak'a, batı da ise Anadolu'ya kadar genişlettiklerini, Abbasi halifesini yönetimleri altına aldıklarını, daha sonra sınırlarını Maveraünnehr, Harezm, Şam, Mısır, Kaşgar, Seyhun'dan Akdeniz'e, Kızıldeniz'e ve büyük okyanusa kadar büyüttüklerini söylemektedir. ${ }^{15}$

Mustafa Kemal Atatürk'ün yeni Türk devletini kurmak amacıyla başlattığı mücadelesi sırasında Osmanlı öncesi Türk tarihine çok önem verdiği ve Türk tarihini bir bütün olarak değerlendirilmesi fikrine sahip olduğu bilinmektedir. Nitekim bu fikri dolayısıyla Cumhurbaşkanlığı forsuna on altı Türk devletinin amblemlerini koyması bunun çok açık bir kanıtıdır. Bu tarihçilik anlayışı Rıza Nur'un kaleminden çıkan Türk Tarihi adlı eserde ileri sürülen daha sonra Fuat Köprülü tarafından geliştirilerek Türk tarihinin bir bütünlük arzettiği, yeni kurulan devletlerin sadece hanedanların değişmesi ile devam ettiği şeklindeki, modern Türk tarihçiliğinde bir ekole dönüşen görüşün Mustafa Kemal Atatürk'ün tarihçilik anlayışına yansıyan izleridir.

1930'lu yıllara gelindiğinde Mustafa Kemal Atatürk'ün tarihçilik anlayışında yeni bir sahnenin açıldığı görülür. Özellikle Türk Tarih Kurumunun ve Türk Dil Kurumunun kurulmasıyla başlayan bu süreç içerisinde Türkiye'nin eski sakinlerinin de Türk olduğu temelinden hareketle gelişen bu tarihçilik anlayışı, aslında yeni kurulan Türk devletine ve Osmanlılıktan Türklüğe geçiş sürecindeki millete Türklük bilincini aşılamak, aynı zamanda dış güçlere karşı Türkiye'nin eski uygarlıkları ile bağlantılarını kurarak buranın asıl sahibi olduğu gerçeğini pekiştirmek için ortaya attığ 1 tarih tezidir. ${ }^{16}$ Nitekim bununla ilgili 1 kasım 1936 tarihli bir konuşmasında "Türk Dil Kurumunun ve Türk Tarih Kurumunun tarihimizin ve dilimizin karanlıklar içinde unutulan yönlerini dünya kültürlerine analıklarını reddolunamaz belgelerle ortaya koydukça yalnız Türk milleti için değil ve fakat bütün ilim alemi için kutsal bir vazife yapmakta" olduğunu söyler ve Tarih Kurumu'nun Alacahöyük'te yaptırdığı kazılarda bulunan belgelerin beş bin beş yüz senelik Türk tarihi belgelerinin dünya tarihinde yeni bir çı̆̆ır açtığını ilave ederken Türk tarihini Anadolu eski

${ }^{15}$ Söylev ve Demeçler, c. I, s. 293.

${ }^{16}$ Özer, a.g.m., s. 762, Ayrıca Mustafa Kemal Atatürk'ün tarih tezi ile ilgili ayrıntılı bilgi için bkz. Afet İnan, “Atatürk ve Tarih Tezi”, Belleten, III/10, (Nisan 1939), s. 243 246. 
uygarlıkları ile irtibatlandırır. ${ }^{17}$ Mustafa Kemal Atatürk'ün bu görüşleri, Rıza Nur'un Türk Tarihi adlı eserinde yer alan Hititler'den Turan Ulusu olarak bahsetmesi ve Asurlardan önce Anadolu'da hüküm süren Elamların ve Sümerlerin Türk olduklarını belirttiği fikirleri ile benzerlik göstermektedir. Nitekim Rıza Nur'un eserinde geçen bilgilerin altını çizmiştir. ${ }^{18}$

Mustafa Kemal Atatürk'ün tarih görüşü açısından etkileyici olan Mısır medeniyetini Türklükle irtibatlandırmasıdır. Mısır Medeniyeti ile ilgili A. Moret'în Nil Nehri ve Misır Medeniyeti adlı eserde geçen Mısır kralı Horus'un yanına $O \breve{g} u z$ ismini not düşerek bu kelimenin Oğuz'dan geldiğini belirtmek istemektedir. ${ }^{19}$ Hatta aynı yazar tarafından kaleme alınan Kabilelerden Imparatorluklara İlkel Toplumlarda ve Eski Doğu'da Sosyal Örgütlenme adlı kitabın bir çok yerine koyduğu notlarda Mısır medeniyetini meydana getirenlerin Türk olduğunu belirtmiş ve bir yerde Mısırlıların hanedan ırkının Akdenizli olduğunu ileri süren yazarın cümlesinin altını çizerek yanına "onlarda türk" notunu düşmüştür. ${ }^{20}$

Mustafa Kemal Atatürk'ün Osmanlı imparatorluğu ile ilgili eleştirel fikirleri olduğu ve bunu meclis kürsüsünden milletvekillerine hitap ettiği bir konuşmasında dile getirdiği tarihen sabittir. Özellikle kendisinin de içerisinde büyüdüğü Osmanlı son dönemi de büyük devletlerin Osmanlı İmparatorluğunu yıkmak üzere ortaya attıkları diplomasinin adı olan "Şark Meselesi” ile ilgili görüşleri vardır. Mustafa Kemal Atatürk'ün, Şerafettin Turan tarafından önceleri çok etkilendiği fakat sonraları eylemleri ile etkilerini silmeye çalıştığ bellirtilen $^{21}$ doğu sorunu ile ilgili görüşleri şunlardır "Garb alemi Osmanlı devletini yıkmak için ortaya Şark Meselesi namile bir mesele çıkarmıştı. Garb öyle zannediyordu ki, Osmanlı devletini yıkmakla onu vücuda getiren unsuru asliyi de yıkacaktı. Garb alemi hâlâ bir hakikati görmek ve itiraf etmek istemiyor ki, o da eski Osmanl devletinin mahv munkariz olduğu ve yeni Türkiye devletinin saha arâyı zuhur olduğudur. Türk milleti kendi ismine izafetle bir devlet vücuda getirmiş, azim ve kudretile yeniden meydana çıkmıştır."22

Mustafa Kemal Atatürk bunun yanı sıra Osmanlı imparatorluğu ve hükümdarları hakkında da eleştirel görüşler belirtmektedir. Özellikle Fatih, Yavuz ve Kanunî gibi Osmanlı hükümdarlarını izledikleri politikaları şahane bulmakla birlikte eksik yanlarının olduğunun altını çizer ve onları eleştirir..

${ }^{17}$ Söylev ve Demeçler, c. I, S. 406. Ayrıca Mustafa Kemal Atatürk dönemi tarih araştırmaları için bkz. K. Bittel, "Atatürk ve İlköz Tarih Araştırmaları”, Belleten, III/10, (Nisan 1939), s. 203-205.

${ }^{18}$ Atatürk'ün Okuduğu Kitaplar, c. I, s. 221, 224.

${ }^{19}$ Atatürk'ün Okuduğu Kitaplar, c. XIII. s. 29.

${ }^{20}$ Atatürk'ün Okuduğu Kitaplar, c. XVIII. s.278.

${ }^{21}$ Şerafettin Turan, Atatürk'ün Düşünce Yapısını Etkileyen Olaylar Düşünürler Kitaplar, TTK yay. Ankara 1989, s. 47.

${ }^{22}$ Söylev ve Demeçler, c. II, s. 93. 
Mustafa Kemal Atatürk'e göre bu her üç hükümdar da kendi hırsları ile yaptıkları ve Fatih'in Bizans'a sahip olurken, Yavuz'un bütün Asya'ya sahip olmak isterken Kanunî'nin ise her ikisine sahip olmak isterken asıl unsur olan Türkleri asker olarak kullandığını; lisanları, dinleri, ananeleri, her șeyi başka başka olan ve bir çok milletlerden ibaret olan bütün bu şeyleri mahfuz burakabilecek istisnalar, imtiyazlar bahșettiklerini, bunu yaparken de asıl unsurun "fütuhat meydanlarında ölmekle, zaptolunan memleketlerin kendisini ve halkın beslemekle ve anlara bekçilik etmekle kendini tahrip ettiğini" söyleyerek Osmanlının bir eleştirisini yapmaktadır. ${ }^{23}$ Eleştirisi, Osmanlı hakanlarının bu fetihlerde asıl unsurunun ölmesine sebep olurken daha sonraları gayrimüslimlere her șeyin hukukî bir hak olarak verilmeye başlandığını ve bunun neticesinde de gayrimüslimlerin yeni bir takım imtiyazlar elde ederek bu imtiyazlarını büyüttüklerinden daha sonraları saraylardaki debdebeden dolayı Osmanlının iktisadi hayatını da ele geçirdiklerini ve Osmanlı maliyesini ellerine geçirmelerinden bahseder ve bu durumun yol açtığı Dûyun-ı Umumiye'nin Osmanlı'nın başına bela olduğunu belirtir. ${ }^{24}$ Mustafa Kemal Atatürk'ün Osmanlının çok uluslu, çok dilli ve çok dinli imparatorluk yapısına yaptığı bu eleştirel fikirlerinin temelinde tek uluslu, tek dilli ve tek dinli Ulus Devlet yaratma fikrinin haklı izleri görülmektedir. Mustafa Kemal Atatürk'ün bu fikirleri, çağdaşı ve batıcı fikirleri ile tanınan gazeteci Celal Nuri'nin görüșleri ile benzerlik göstermektedir. Celal Nuri bu yöndeki fikirlerini, Türk Devrimi adlı kitabında uzun uzun açıklamaktadır. ${ }^{25}$

Mustafa Kemal Atatürk'ün hemen her planının arkasında tarih biliminden nasıl faydalandığına en güzel örneklerden birisi de Ankara'nın merkez yapılmasında gözlemlenebilir. Ankara'nın başkent olmasının en önemli nedeni yine Mustafa Kemal Atatürk'ün tarih biliminden kaynaklanan bilgisinden ileri gelmektedir. Ankara ile ilgili şunları söylemektedir:"Ben Ankara'yı coğrafya kitabından ziyade tarihte öğrendim. Hakikaten Selçukî idaresinin inkısamı üzerine Anadolu'da teşekkül eden küçük hükümetlerin isimlerini okurken birtakım beylikler meyanında bir de Ankara Cumhuriyetini görmüşü̈m. Tarih sahnelerinin bana bir cumhuriyet merkezi olarak tanıttığı Ankara'ya ilk defa geldiğim o gün de gördüm ki orada geçen asırlara rağmen Ankara'da hala o cumhuriyet kabiliyeti devam ediyor..."

Mustafa Kemal Atatürk'ün tarih bilgisi ve bilincinin son derece ileri olduğu buraya kadar anlatılanlardan anlaşılmaktadır. Hatta okuduğu kitaplarda yanlış olduğunu tespit ettiği bilgileri düzelterek kitapların yanına notlar düşmekteydi. Ahmet Rasim'in kaleme aldığı Osmanlı Tarihi adlı eserde Osman Beyin babası Ertuğrul'un savaş sırasında zayıf olduğu ve bu

\footnotetext{
${ }^{23}$ Söylev ve Demeçler, c. II, s. 105-106.

${ }^{24}$ Söylev ve Demeçler, c. II, s. 107-108.

${ }^{25}$ Celal Nuri, Türk Devrimi, (Günümüz diline akt. Özer Ozankaya), Kültür Bakanlığı yay. Ankara 2002, s. 22-35.

${ }^{26}$ Söylev ve Demeçler, c. III, s. 98.
} 
sebeple yenildiğini gördüğü kuvvetlere yardım ettiği ve sonra bu kuvvetlerin Selçuklu kuvvetleri olduğunu öğrendiğini ileri süren görüşüne karşı "Hayır öyle değil müzakere sonrasında karar verildi ." notunu düşerken ${ }^{27}$ ayn1 yazarın I. Mahmut'u IV Murat'ın oğlu olarak gösterdiği sayfa kenarına düzeltme yaparak I. Mahmut'un II. Mustafa'nın oğlu olduğunu yazmıştır. ${ }^{28}$ Ziya Gökalp'in, Türk Medeniyeti Tarihi adlı kitabında ise Gökalp'in Oğuz Han olarak tanımladığı tarihi şahsiyetin M.Ö 209 tarihindeki Hun Hükümdarı olan Mete Han olduğunu yönündeki notunu düşmüştür. ${ }^{29}$

Diğer taraftan Mustafa Kemal Atatürk'ün Türk Tarih Kurumunun liseler için hazırlattı̆̆ $\breve{g}_{1}$ İslam tarihi konusunda yazılan kitabın İslam Peygamberinin hayatı ile ilgili kısımları beğenmediği ve Hz. Muhammet'in hayatı ve savaşları ile ilgili bölümleri kendisinin yazdığı bilinmektedir. ${ }^{30}$

Sonuç olarak şunu söylemek gerekir ki devlet adamı, asker, düşün adamı sıfatlarına sahip Mustafa Kemal Atatürk'ün aslında bütün bu vasıfları, iyi bir tarih bilgisi ve tarih bilincine sahip olmasından kaynaklanmaktadır. Mustafa Kemal Atatürk'ün hayatına ve söylemlerine kronolojik olarak bakıldığında ve bunlar alt alta koyulduğunda ortaya bir Türk tarihi belgeseli çıkmaktadır. O'nun bu bilgi birikimine ulaşması için okuduğu tarih kitaplarına bakıldığında da ne kadar geniş bir perspektif ve bilgi birikiminin olduğu daha iyi anlaşılır. Mustafa Kemal Atatürk’ün yukarıdaki sıfatlarının yanında çok iyi bir tarihçi olduğu ve tarihçiliğin devlet adamı, asker veya düşün adamı için ne kadar gerekli bir bilim dalı olduğu da şahsında kendini göstermektedir. Mustafa Kemal Atatürk'ün tarih bilgisi ve bilinci başlı başına bir örnektir. Bu bilgi ve bilinç ülkelerin, milletlerin varlığında ve bu varlığın yaşatılmasında en önemli unsurlarınđan biridir. İmparatorluların dağılma sürecine girdiği bir dönemin sonunda parçalanmaya ve yok olmaya giden Türk devleti ve milletinin, küllerinden yeniden doğarcasına Türkiye Cumhuriyetini ortaya çıkarmasında Mustafa Kemal Atatürk'ün sahip olduğu tarih anlayışı en önemli etkenlerden birisi olarak karşımıza çıkmaktadır. Bu tarih anlayışı, beş bin beş yüz yıllık Anadolu'nun Türklüğü fikrinden hareketle yeni kurulacak Türkiye Cumhuriyetinin bu toprakların gerçek sahipleri olan Türk ırkına ve diline dayalı (tek uluslu ve tek dilli) ulus devlet yani Türk Devleti modelinin temelini oluşturmaktadır. Mustafa Kemal Atatürk yeni Türkiye Cumhuriyetini oluşturan Türk milletine bu şuuru aşılamak ve benimsetmek için özellikle Türklük bilincinin ${ }^{31}$ oluşması için çaba sarfetmiş ve bunu gerçekleştirirken de tarih biliminden faydalanarak bu

${ }^{27}$ Atatürk'ün Okuduğu Kitaplar, c. II, s. 27.

${ }^{28}$ Atatürk'ün Okuduğu Kitaplar, c. II, s. 83.

${ }^{29}$ Atatürk'ün Okuduğu Kitaplar, c. II, s. 14.

${ }^{30}$ Turan, a.g.e., s. 29, Mustafa Kemal Atatürk'ün İslam tarihi ile ilgili görüşleri için bkz. Sabri Hizmetli, "Mustafa Kemal Atatürk'ün İslam Tarihi Anlayışı", Atatürk Araştırma Merkezi Dergisi, XV/44, (Temmuz 1999), s. 457-486.

${ }^{31}$ Mustafa Kemal Atatürk’teki Türklük şuuru hakkında geniş bilgi için bkz. Korkmaz, a.g.m., s. 47-60. 
bilincin oluşmasına katkı sağlamayı amaçlamıştır. Türk Ocaklarının kuruluşunun amacı da Türklük bilincinin gelişmesini sağlamaktır ${ }^{32}$ Son söz olarak; yüzyıllardır Osmanlı tebası olarak ve Osmanlılık kimliği ile ümmet olarak yaşayan Türklere yeniden Türk kimliğini kazandırmak Mustafa Kemal Atatürk'ün en önemli devrimlerinden biri olduğunu bunda da en önemli rolü Mustafa Kemal Atatürk'ün düşün dünyasında şekillenen tarih bilgisi ve bilincinin oynadığını belirtmek gerekmektedir.

\footnotetext{
${ }^{32}$ Keskin, a.g.m., s. 366 .
} 


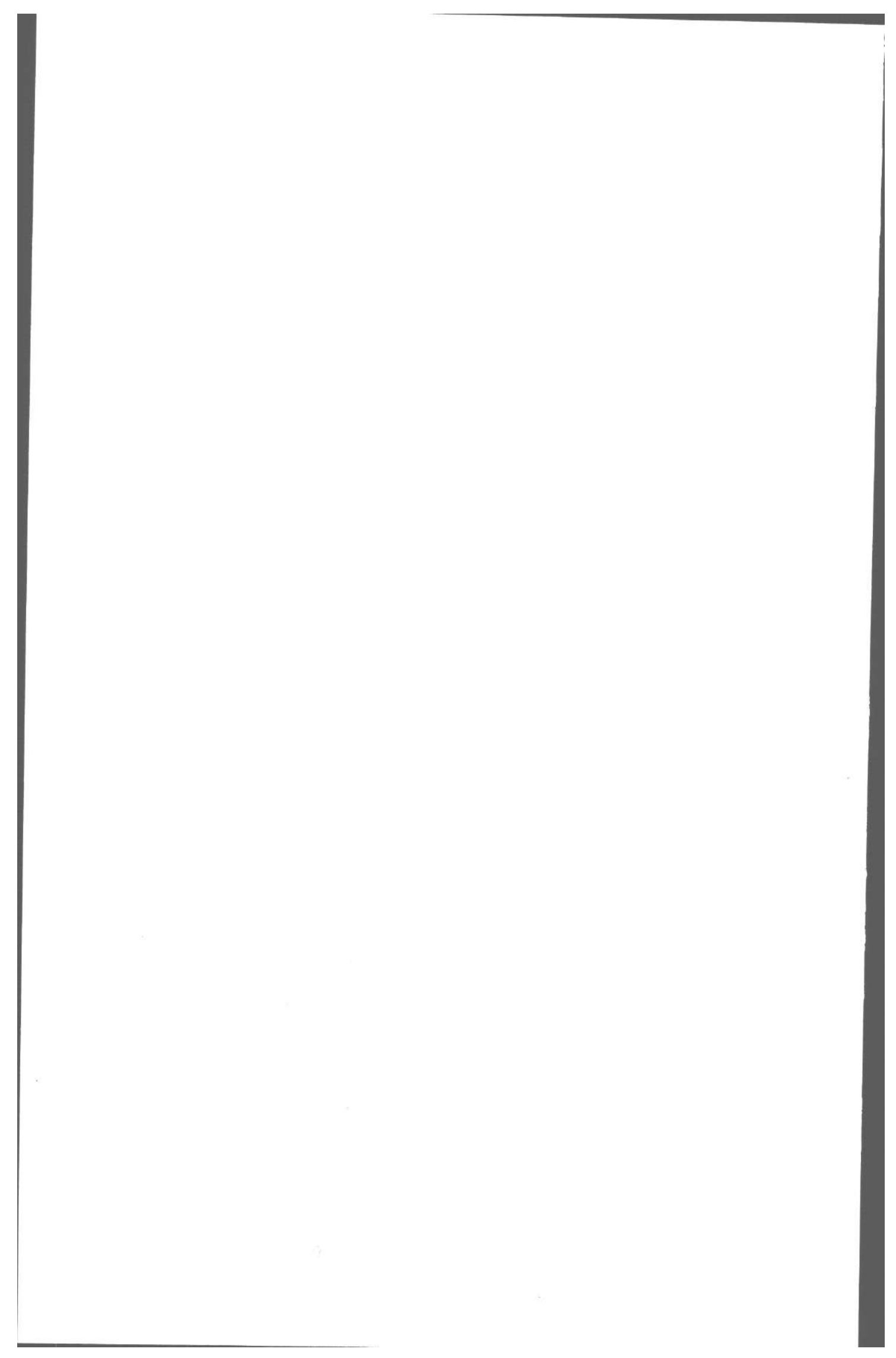

